\title{
Das cantigas do beco: cidade e sociedade na poesia de Cora Coralina*
}

\author{
Clóvis Carvalho Brito**
}

\begin{abstract}
Resumo: Este artigo analisa as interconexões entre literatura e sociedade no poema "Becos de Goiás", de Cora Coralina (1889-1985). Nesse poema, observamos as relações sociais no interior brasileiro nos séculos XIX e XX, sob o olhar da periferia, dos que estavam à margem na considerada "boa sociedade", percorrendo cenários, personagens e destinos que divergem dos privilegiados tradicionalmente. Pretendemos, pela descrição dos becos, válvulas coronárias da velha cidade, analisar as estratégias utilizadas pela autora para retratar e criticar a realidade de seu tempo.
\end{abstract}

Palavras-chave: cidade; poesia; sociedade.

\begin{abstract}
A poetisa Cora Coralina (1989-1985), em diversos momentos de sua obra, destaca a literatura como uma forma de recriação. A autora tinha consciência de que os seus versos constituem uma fonte privilegiada de compreensão da vida social porque "têm a vida", "entram na realidade" e "representam uma recriação da vida". Por isso, em diversas passagens, congrega seus leitores a uma participação, a um diálogo com sua obra, tarefa que, a partir deste momento, procuraremos realizar. Compete, desse modo, no decorrer das avaliações, tentarmos obter respostas a alguns questionamentos: que vida é recriada por Cora Coralina? Quais as experiências retratadas? Qual era a participação desejada pela poetisa?

Uma leitura dos significados fornecidos pela poesia de Cora Coralina conduz à identificação
\end{abstract}

\footnotetext{
* O presente artigo é uma adaptação de um item da dissertação Sou Paranaíba pra cá: literatura e sociedade em Cora Coralina, realizada no Programa de Pós-Graduação em Sociologia da Universidade Federal de Goiás - UFG. Agradeço a orientação da professora dra. Maria Cristina Teixeira Machado e os comentários e sugestões das professoras dras. Mariza Veloso (UnB) e Solange Yokozawa (UFG).

** Doutorando em sociologia pela UnB na linha de pesquisa arte, cultura e pensamento social. E-mail: clovisbritto5@ hotmail.com.
}

de importantes aspectos da história e da sociedade goianas. A longevidade da autora contribuiu para que sua obra manifestasse distintas influências e retratasse elementos que, em conjunto, possibilitam recompor as relações entre gêneros, classes e gerações, as disputas pelo poder, as representações dos modos de vida, valores e crenças, enfim, as mediações entre os indivíduos e a sociedade na qual esteve inserida. As imagens tecidas através de sua criatividade ampliam as perspectivas de análise das lutas travadas nos séculos XIX e XX no interior brasileiro e, em um diálogo entre texto poético e contexto sóciohistórico, denunciam e refletem entraves e belezas, desnudando múltiplas e silenciadas nuanças da sociedade goiana. Para a compreensão desse imaginário, compete inicialmente estabelecermos as relações entre a crítica literária e a análise sociológica, em sentido estrito.

De acordo com Bourdieu (1996a), a autonomia da arte e do artista é uma autonomia relativa em um espaço de jogo (campo) pautado sobre determinadas condições. Compreendendo o campo como espaço social de relações objetivas e observando os capitais progressivamente acumulados, pode-se indagar até que ponto uma obra é reflexo das situações vivenciadas pelo 
autor e forma de resistência, de contestação aos ditames dos legitimados e estabelecidos. As lutas pela distinção travadas nesse espaço de possíveis seriam o motor do campo, e tais disputas e mecanismos de manutenção de poder, necessariamente, implicariam reflexos nos agentes envolvidos - no caso do campo literário, nos escritores, nas obras, no público leitor, mediadores, dentre outros. Para tanto, torna-se fundamental a análise da crença, "a fabricação material do produto, transfigurado em 'criação', com isso desviando a busca, para além do artista e de sua atividade própria, das condições dessa capacidade demiúrgica" (Bourdieu, 1996a, p. 193) e das relações ocorridas no seio do campo: todo o "conjunto daqueles que contribuem para o 'descobrir' e consagrar enquanto artista 'conhecido' e reconhecido - críticos, prefaciadores, marchands etc" (p. 193).

Bourdieu demonstra que os determinismos sociais que deixam marcas na obra de arte são exercidos, por um lado, através do habitus do produtor, remetendo, assim, às condições sociais de sua produção como sujeito social (educação familiar, escolar, por exemplo) e como produtor (estilo, contatos profissionais etc.) e, por outro lado, através das demandas e das coerções sociais inscritas na posição que ele ocupa no campo de produção. O que se chama "criação" seria o encontro de um habitus socialmente constituído e uma certa posição já instituída ou possível na divisão do trabalho de produção cultural (e na divisão do trabalho de dominação), trabalho através do qual o artista realiza sua obra e, inseparavelmente, se faz como artista. O habitus seria, nesse entendimento, um princípio "gerador e unificador que reduz as características intrínsecas e relacionais de uma posição em um estilo de vida unívoco, isto é, em um conjunto unívoco de escolhas de pessoas, de bens, de práticas" (Bourdieu, 1996a, p. 2). Das orientações, observamos que, se o sujeito da obra é um habitus em relação a um campo, o que deve ser avaliado não é o artista singular, mas o campo da produção artística em seu conjunto. A sociologia não poderia compreender a obra de arte, e, principalmente, aquilo que acarretaria sua singularidade, se elegesse como objeto o autor e sua obra em estado isolado. Desse modo, devemos considerar o campo literário como um campo de forças que age sobre aqueles que estão em seu interior, de uma forma diferenciada de acordo com a posição ocupada, provocador de concorrências que tendem à conservação ou à transformação.

Para Bourdieu (1996b), a obra de arte deve ser compreendida a partir das regras originárias no campo de sua formação. A arte não é um terreno sagrado que deve ser mantido fora da avaliação científica. Cabe à sociologia não um estudo estético, como o realizado pela crítica literária, e sim a percepção dos processos que estão na base da composição artística. Mas como seria essa análise sociológica da literatura?

$\mathrm{O}$ autor combate a idéia da autonomia da literatura e da transcendência das obras culturais, argumentando que a análise científica da obra literária contribui para seu enriquecimento. Descreve as tradicionais formas com que os analistas têm tratado o texto literário, concluindo que mascaram as relações objetivas, ou seja, a estrutura que determina a forma das interações.

A primeira vertente citada é a do mito fundador ou "projeto original", que induz à idéia de um intelectual onipotente. A representação carismática do autor como criador deve ser superada através do estudo da gênese e da estrutura do espaço cultural específico no qual o autor se inseriu e onde o seu projeto criador foi formado. Outras críticas são lançadas às correntes de tradição estruturalista que procuram estudar o fenômeno literário literariamente, buscando as condições da experiência estética e investigando a essência da literatura sem referências externas. Também critica a denominada crítica genética, por buscar a gênese do texto no próprio texto. Esse formalismo, que privilegia as respostas auto-referenciais (absolutização do texto), causaria um reducionismo que esconde as hierarquias e as espécies de efeitos de dominação simbólica. Já tendências que privilegiam as análises externas predispõem a ignorar a lógica interna dos objetos culturais, contribuindo para o esquecimento dos agentes e das instituições que o produziram. Essa corrente, de influências marxistas, ao promover atenção exclusiva às funções, realizaria o inverso do apregoado pela tradição internalista. Segundo dispõe, 
a eficácia dos fatores externos, crises econômicas, transformações técnicas, revoluções políticas ou, muito simplesmente, demanda social de uma categoria particular de comanditários, de que a história social tradicional busca a manifestação direta nas obras, não pode exercer-se senão por intermédio das transformações da estrutura do campo que esses fatores podem determinar. (Bourdieu, 1996b, p. 232)

Conclui que a noção de campo permitiria superar a oposição entre leitura interna e análise externa, sem perder as aquisições e as exigências dessas abordagens: "ocorre que a estrutura da obra, que uma leitura estritamente interna traz à luz, ou seja, a estrutura do espaço social no qual transcorrem as aventuras [...], é também a estrutura do espaço social no qual seu próprio autor estava situado" (Bourdieu, 1996b, p. 17).

Orientação que estabelece pontos de contato com as análises de Antonio Candido (1976), ao entender que a compreensão das obras culturais deve ser efetuada a partir da fusão texto e contexto, instâncias necessárias ao processo interpretativo. A aproximação da forma e do conteúdo das poesias com o contexto em que foram produzidas permite, no método de Candido, relacionar a posição do autor com a natureza das produções e, conseqüentemente, recuperar a organização social da época através dos valores e ideologias expressos na obra. $\mathrm{O}$ autor sustenta que a crítica literária deve abraçar o postulado de que o externo (o social) só interessaria na medida em que se faz interno, em que se integra à própria estrutura estética da obra. Segundo seu entendimento, a sociologia moderna deveria analisar os tipos de relações e os fatos estruturais ligados à vida artística, sejam como causa ou como conseqüência. Para tanto, seria necessário investigar as influências concretas apresentadas pelos fatores de ordem sociocultural, dentre os quais os mais decisivos se ligariam à estrutura social, aos valores e ideologias e às técnicas de comunicação.

Sua análise revela que os aspectos relativos à estrutura social se manifestariam de forma mais visível na definição da posição social do artista ou nos grupos receptores; já valores e ideologias poderiam ser extraídos na forma e no conteúdo da obra, e as técnicas de comunicação se demonstrariam na avaliação da sua fatura e transmissão: "todo o processo de comunicação pressupõe um comunicante, no caso o artista; um comunicado, ou seja, a obra; um comunicando, que é o público a que se dirige; graças a isso define-se o quarto elemento do processo, isto é, o seu efeito" (Candido, 1976, p. 21). Em seu entendimento, devemos analisar sociologicamente a produção em seus quatro momentos: a) o criador que através de uma necessidade particular a orienta conforme as influências de seu tempo; b) a definição de determinadas temáticas; c) a utilização de certas formas, e d) o resultado dessa síntese e sua ação sobre o meio. Em sua proposta, destaca que a obra literária só poderia ser compreendida na fusão do texto e do contexto, fornecendo subsídios à interpretação dos dois momentos. Segundo afirma, as modalidades de estudo sociológico não deveriam ser utilizadas como orientação estética, mas como teoria e história sociológica da literatura - sociologia da literatura -, o que possibilitaria, a partir do texto literário, encontrar imagens e enunciações que evidenciariam as interconexões entre literatura e sociedade.

Elegemos os referenciais teórico-metodológicos de Candido e Bourdieu, partindo do pressuposto de que possibilitariam um efetivo exercício de investigação sociológica das obras culturais: a idéia de campo possibilitaria desvendar o que Candido define como crítica - captar a estrutura social na estrutura da obra, ou seja, perceber como os elementos exteriores à criação literária, como o meio e a sociedade, interferem na estrutura interna da obra. Todavia, não é intenção da pesquisa promover a investigação de todas as imagens que compõem o imaginário expresso por Cora no poema, mas daquelas que remetem a elementos sociológicos considerados significativos para a nossa proposta.

Como o contexto teria influenciado o texto poético e em que medida o texto expressa esse contexto? As lutas travadas pela inserção, as preferências estilísticas, a adoção de determinadas temáticas e personagens, dentre outras estratégias no espaço de possíveis, constituem pistas para que encontremos essa resposta. 
Partindo desse entendimento, pretendemos descortinar instigantes facetas da expressão literária de Cora Coralina. Para tanto, torna-se necessário buscar compreender a obra de arte e, com efeito, pressupõe indagar "a visão de mundo própria ao grupo social a partir ou na intenção do qual o artista teria composto sua obra e que, comanditário ou destinatário, causa ou fim, ou os dois ao mesmo tempo, ter-se-ia exprimido através do artista" (Bourdieu, 1996b, p. 230), por intermédio das transformações estruturais do campo em que tais produções foram criadas. Interessa, portanto, observar como Cora Coralina pensou a sociedade de seu tempo. Quais as temáticas e estratégias utilizadas? Quais os destinatários principais ou privilegiados?

Convém verificarmos as leituras promovidas pelos críticos, resumidas na abordagem de Alencastro (2003), ao demonstrar que os mecanismos acionados nos poemas de Cora constituem formas que possibilitam subverter a ordem estabelecida, fornecendo novas leituras do homem e do mundo. Seriam instrumentos de humanização do leitor, mesmo que, para tanto, a autora lhe mostre o avesso, os arredores, os marginalizados. Desse modo,

vê-se uma Cora que não se fez poetisa para louvar os grandes, os importantes, o poder institucionalizado: Cora se fez poeta para lembrar à sociedade de Goiás que existe uma periferia marginalizada. [...] A crítica social está pulsando nos poemas da escritora denunciando uma sociedade estratificada e injusta. [...] A sua percepção não é a mesma da infância; alteraram-se os juízos de valor. Portanto, a memória de Cora está amarrada à memória do grupo, e ela procura soltar essas amarras legitimando os grupos marginalizados da sociedade. (Alencastro, 2003, p. 86-87)

É relevante identificarmos o lugar onde ocorrem as relações descritas pelo imaginário da poeta: a poesia de Cora Coralina é a poesia da cidade de Goiás. Não há como negligenciar o laço umbilical da "aquém-Paranaíba". A poetisa deixa transparecer sua opção no antológico poema "Minha cidade": "Goiás, minha cidade...", assim o inicia, revelando-se cúmplice das situações que descreve. A partir desse entendimento, podemos ousar e dialogar com a definição de memória topográfica de Willi Bolle (2000), formulada quando identificou na obra de Walter Benjamin afinidades entre as estruturas da cidade e dos indivíduos que nela vivem. Em suas interpretações, história, biografia e mitologia seriam fios de um mesmo tecido - a memória. A memória topográfica não reconstruiria os espaços pelos espaços, eles se tornariam pontos de referência para captar experiências sociais e espirituais.

A cidade de Goiás transformou-se em palco para o estabelecimento dessa memória repleta de significados, captados e reconstruídos por Cora entre um exercício de afetividade e percepção crítica. Conforme ensina Machado (2002), a cidade tem aspectos físicos e uma vida interior, em um mecanismo contínuo que funde a vida com sua configuração espacial. Dessa forma, os aspectos urbanísticos seriam um fio condutor para a compreensão do que a pesquisadora define como cidade-vida, cidade-história, cidadesociedade, cidade-cultura. É em busca dessa cidade, em suas múltiplas dimensões, que a análise proposta neste artigo se desenvolverá. Pretendemos, a partir do poema "Becos de Goiás", do livro Poemas dos becos de Goiás e estórias mais (1965), evidenciar as relações ocorridas na sociedade goiana e perceber o que a cidade e seus habitantes têm a dizer através dos versos de Aninha.

Trilhar os caminhos de Cora é andar descalço nas pedras de sua cidade, ouvir as casas cochichando umas com as outras, folhear um livro portador e provocador de sentidos. De seus escritos emerge uma diversidade de elementos importantes para a compreensão do mundo social. Porém, entendemos que, dentre as cenas repletas de conteúdo sociológico, as imagens do beco se sobressaem no imaginário da autora. Em vários poemas e contos, a vida da cidade é traduzida a partir da vida nos becos, dos personagens que nele residem e circulam, das relações e reações que provocam como palco ou bastidor. O beco contrapunha-se ao largo. Enquanto os largos eram ligados pelas ruas principais, onde viviam as famílias da sociedade reconhecida, os becos eram construções para facilitar o acesso às ruas, geralmente surgindo na confluência dos quintais e funcionando como repositório de tudo o que a sociedade desejava 
evitar. O beco é o lugar a partir do qual Cora Coralina desvendou a vida da sociedade de seu tempo.

Segundo Yokozawa (2002), a memória em Cora Coralina é uma memória espacializada, fossilizada no espaço, e o espaço mnemônico da poetisa seria o espaço da cidade de Goiás, mesmo quando seus textos privilegiam outros rincões brasileiros. Ao perscrutar a memória guardada pela sua cidade, a literata teria apreendido uma dimensão humana que desconhece fronteiras regionais, conferindo à sua poesia uma dimensão universal. Observa que os becos são um dos espaços de memória eleitos por Cora e conservam as estórias das "vidas obscuras" resgatadas pela sua poesia:

Mesmo quando recupera outros espaços, quando percorre outra geografia que não a goiana, pode-se dizer que a poesia coralineana é, metaforicamente, uma poética dos becos. É o que acontece, por exemplo, quando Cora visita poeticamente o Palácio Conde dos Arcos. [...] No paço, a poetisa encontra não os governantes de província que por lá passaram, mas o índio carajá, um soldado civilizado que, um dia, tendo seus atavismos despertados por um trovão, despiu a roupa e a civilidade e sumiuse no rumo do Araguaia. É o que acontece também quando Coralina percorre outros sítios, donde desentranha heróis como Lampião, Tiradentes, os judeus errantes e o obscuro Campos Sales, não o ex-presidente, mas um negro sobrevivente da Guerra do Paraguai. (Yokozawa, 2002, p. 10)

Abraçando essa orientação, passemos à análise poemática com o intuito de relacionar forma expressiva e temporalidade que, segundo Machado (2002), possibilita refletir "sobre a construção do conhecimento a partir de campos discursivos que se interpenetram tais como a ciência e a literatura" (p. 10).

\section{Becos de Goiás: cenários, personagens e destinos}

Quando Cora retornou à cidade de Goiás, em 1956, e começou a gestar o poema que será aqui analisado, os reflexos da mudança da capital para Goiânia e do tradicionalismo ainda perma- neciam vivos no imaginário dos moradores. Esse fato pode ser observado em "O cântico da volta":

A cidade-mãe nem me surpreendeu, nem me desencantou. Conservada, firme, bem empostada, tem recatos de mistério, tem feitiço de prender. [...] Sentiu com altivez o tremendo impacto da mudança. Não se despovoou nem se desagregou com a grande espoliação. [...] E a gente da velha ala? Enraizada como velhas figueiras, agarrada às tradições e aos encantamentos da terra, sustentáculos, colunas, e cariátides; embasamento, concreto e arcabouço, amparo e anteparo da cidade frustrada. Velhas sentinelas que morrem no posto de honra. (Coralina, 2001b, p. 102-108)

De acordo com Fraga (2005), a idéia de tradição comandou e comanda, até hoje, as representações que os agentes sociais fazem da cidade de Goiás e de sua vida coletiva, legitimando e autorizando o tradicionalismo portador de regras antigas que retratam formas de vida e moldam classificações e hierarquias na busca pela distinção. Sendo uma "dimensão da vida social, a tradição se impõe como um valor da maior importância, porque não é apenas o passado: é, sobretudo, uma realidade que confere estabilidade e continuidade ao modo de vida e à cidade" (Fraga, 2005, p.37). As famílias, por meio de seus nomes, se monumentalizam e "pertencer ao pólo dominante significa contar com a probabilidade de encontrar submissão de determinado grupo de pessoas, por diversos motivos, inclusive hábitos inconscientes" (p. 65). A cidade de Goiás era constituída por uma sociedade em que o mundo oficial era ditado pelas práticas conservadoras, das famílias que residiam nos largos e ruas principais, que elegeram os becos como locais dos segregados. Colocados à margem pelos dominantes, os becos se constituíram na principal fonte de inspiração de Cora Coralina. Alencastro (2003) ressalta que, nos poemas de Cora, a descrição da cidade pela identificação do "eu poético" se efetua nos espaços, logradouros e detalhes que não foram reconhecidos como os tradicionais marcos de Goiás, contrariando a visão do elitismo e da monumentalidade. Assim, a poesia traduz o ambiente a partir dos lugares onde viviam os dominados e "é significativa a identidade de Cora 
com a cidade que não corresponde à do cartãopostal. Ao contrário, distancia-se da visão romântica da velha cidade e dirige seu olhar para os espaços obscuros, esquecidos" (Alencastro, 2003 , p. 91). Cora, ao recriar poeticamente uma Goiás do passado, também revela um Brasil recém-republicano.

Goiás acompanhou os movimentos liberais e as mudanças sociais ocorridas no país durante o século XIX de uma forma tímida. Segundo Palacin (1989), a transformação do regime monárquico em republicano ocorreu sem grandes dificuldades, já que a abolição não teria afetado a vida econômica da província. No Brasil, o movimento republicano somente tomou corpo a partir de 1870, década de transformações socioeconômicas: surto cafeeiro, impulsos à industrialização, incremento à imigração européia, urbanização, dentre outras. Mas em Goiás, graças a sua estrutura socioeconômica e cultural, as manifestações republicanas foram tardias e inexpressivas. Na República, a idéia de atraso ganhou uma dimensão mais política do que econômica. Para Chaul (2002), o estado seria o representante memorial desse atraso e a pecuária o meio para sair do marasmo provocado pela decadência da mineração.

O estudo de Campos (2003) destaca algumas características que possibilitam construir um retrato de Goiás na Primeira República a partir da economia, demografia, situação geográfica e de comunicação. O autor afirma que a economia goiana, nesse período, tinha a pecuária como elemento fundamental. Aliado a essa principal atividade econômica, o fato de a população se concentrar na área rural contribuiu para que o estado se tornasse agrário por excelência. Goiás contava com uma inexpressiva população, da qual uma pequena parcela vivia em vilas ou pequenas cidades. A própria localização geográfica contribuiria para o isolamento, em um país de economia de exportação, quase sem mercado interno, com dificuldade de comunicação e transporte. Campos afirma que esse conjunto de fatores, somado à pequena bancada de representantes federais, reforça a situação de periferia, de marginalização do estado. Todavia, dentro de um país marginal, e de um estado marginal, Cora Coralina opta por contar a história de seu tempo e lugar a partir de um local e de personagens também periféricos.

No poema "Becos de Goiás", a literata revela o amor que devota a esse local obscuro e homenageia todos os becos da cidade, locais destinados aos "destituídos" da história e do espaço. Cora proporcionou a descrição - estreita fisicamente e larga imageticamente - desse cenário:

Beco da minha terra...

Amo tua paisagem triste, ausente e suja.

Teu ar sombrio. Tua velha umidade andrajosa.

Teu lodo negro, esverdeado, escorregadio.

E a réstia de sol que ao meio-dia desce, fugidia, e semeia polmes dourados no teu lixo pobre, calçando de ouro a sandália velha, jogada no teu monturo.

Amo a prantina silenciosa do teu fio de água, descendo de quintais escusos

sem pressa,

e se sumindo depressa na brecha

de um velho cano.

Amo a avenca delicada que renasce na frincha de teus muros empenados, e a plantinha desvalida, de caule mole que se defende, viceja e floresce no agasalho de tua sombra úmida e calada.

Amo esses burros-de-lenha que passam pelos becos antigos.

Burrinhos dos morros, secos, lanzudos, malzelados, cansados, pisados.

Arrochados na sua carga, sabidos, procurando a sombra,

No range-range das cangalhas.

(Coralina, 2001a, p. 92)

A escritora define o beco como um lugar que provoca evocações negativas: triste, ausente, sujo, sombrio, velho, pobre, úmido e escorregadio. Porém, o beco desperta o seu amor pelo que congrega de belo em meio à degradação e pela vida que contém: a que renasce e que busca sobreviver a despeito de sua fragilidade e das condições desfavoráveis. Também remete a um ambiente onde, apesar de reinarem a ausência e o abandono, era capaz de fornecer condições para que os burros-de-lenha executassem suas atividades.

Nos séculos XVIII e XIX, os principais meios de transporte utilizados em Goiás eram 
os animais cargueiros (burros e mulas), e o encarregado por conduzi-los era denominado tropeiro. As poucas estradas existentes no país eram transitadas por carros de boi, carruagens e, principalmente, por cargueiros. Com o advento das ferrovias e do transporte automotor, essas viagens de longa distância não mais se justificavam, e os tropeiros se resumiram ao cumprimento de funções consideradas domésticas ou aos pequenos serviços: "carregar o carro, jungir os bois, pegar na despensa da casa grande mantimento para a viagem - quatro dias ida e volta, receber a lista das encomendas" (Coralina, 2001c, p. 97). Atividade essencialmente masculina, foi por muitos anos fonte de renda de trabalhadores que vendiam nas cidades leite, verduras, cereais e feixes de lenha. Na cidade de Goiás, era comum o dito popular segundo o qual "quem não governa a lenha, não governa a casa que tenha", delimitando o universo da mulher na sociedade e legitimando o acesso dos lenheiros às casas de "conceito". Esses trabalhadores assumiram a função de estreitar os laços da cidade-vida, efetivando a ponte entre o mundo marginal e o mundo oficial. Os becos que, a princípio, foram criados apenas para encurtar as distâncias transformaram-se em locais para a circulação de serviçais e animais. E entre evocações negativas e declarações de amor, a autora identifica um primeiro personagem do beco:

E aquele menino, lenheiro ele, salvo seja.

Sem infância, sem idade.

Franzino, maltrapilho,

pequeno para ser homem,

forte para ser criança.

Ser indefeso, indefinido,

que só se vê na minha cidade.

Amo e canto com ternura

todo o errado da minha terra.

(Coralina, 2001a, p. 93)

O menino lenheiro circula pelo beco desenvolvendo sua atividade cotidiana, e a poetisa, ao descrevê-lo, denuncia as conseqüências das relações de trabalho em Goiás. No Brasil, a partir do século XX, os programas sociais instituídos enfocavam o trabalho de crianças e adolescentes como estratégias de combate às formas de marginalidade. Segundo relata Marin (2004), tais idéias mantinham, de certo modo, as concepções historicamente construídas sobre a infância pobre e, na história social da criança brasileira, consolidou-se a ideologia da existência de duas vertentes possíveis para essa infância: a marginalidade ou o trabalho. Um dos trabalhos dos jovens e crianças no interior goiano foi o de lenheiro. Para aumentar a renda familiar, os meninos entregavam os feixes de lenha nas residências e, conforme descreve Cora Coralina, perdiam sua infância tornando-se seres indefinidos: "forte para ser criança e pequenino para ser homem".

Em meio a essa problemática, surge uma idéia-chave na trama: o beco como lugar onde vive e ocorre o considerado "errado" pela sociedade estabelecida. Tornou-se um espaço marginal e sua poética inova ao atribuir-lhe um valor até então negado. De acordo com Silva (2003), ao compor o quadro geográfico e social de Goiás, a poetisa analisa os espaços de poder e os espaços de marginalidade, porém, se fixa nos últimos. A autora identifica que, assim como Cora Coralina, Manuel Bandeira também escreveu um poema que fala sobre o beco: define-o como "espaço de excelência de sua atenção: [...] 'Que importa a paisagem, a Glória, a baía, a linha do horizonte? - O que eu vejo é o beco"" (Silva, 2003, p. 232), destacando um movimento importante na literatura brasileira a partir dos anos 30, quando ocorreu uma mudança das temáticas, principalmente na poesia. Segundo relata, os escritores passaram a evidenciar os problemas, as injustiças e as desigualdades, fazendo poesia a partir da dureza e da marginalidade. Citando Antonio Candido, expõe como características do período a fusão entre a libertação do academicismo, dos recalques históricos, do oficialismo literário, o ardor de conhecer o país e as tendências de educação política e reforma social.

A imagem do beco evidencia a consciência crítica da poetisa. É o relicário da história e, por isso, os sentimentos provocados para intitular seu primeiro livro, Poemas dos becos de Goiás e estórias mais. A partir dos becos, Cora construiu as outras estórias e histórias revelando Goiás - cidade e estado -, para além da Serra Dourada e dos limites do Paranaíba. 
Mais do que matéria para poesias, os becos sempre estiveram presentes no cotidiano dos moradores da cidade de Goiás. A cidade foi reconhecida pela Unesco como Patrimônio Mundial por representar um testemunho da ocupação e da colonização do interior do Brasil. Nos critérios apresentados na Proposta de inscrição da cidade de Goiás na Lista do Patrimônio Mundial (Brasil, 1999), sua concepção urbana seria um exemplo típico de cidade colonial adaptada às particularidades do ambiente, com a utilização de materiais típicos da região na formação de um conjunto único. Traduziria o modo de vida adotado pelos exploradores e fundadores de cidades portuguesas e seria o último testemunho da ocupação do Brasil da forma praticada nos séculos XVIII e XIX. Nesse entendimento, Goiás possui uma estrutura urbana e arquitetônica típica das populações da América do Sul, sendo o primeiro núcleo oficializado e a primeira vila a se organizar a oeste da linha demarcatória do Tratado de Tordesilhas, influenciando toda uma região e constituindo testemunho de um período fundamental da história brasileira.

Segundo Coelho (1999), na estruturação da cidade de Goiás existem vários elementos que contribuíram para que o espaço se organizasse da forma como se encontra atualmente. Tais elementos seriam característicos do modo habitual de organização das cidades no território da metrópole, com influências de origem européia cristã e árabe. As ruas teriam sido definidas a partir da construção dos edifícios de paredemeia, que acompanhavam as ondulações do terreno e formaram uma organização própria com marcantes influências portuguesas. Como conseqüência dessa organização, encontram-se ruas irregulares interligadas entre si por becos muitas vezes sem saída, geralmente atendendo à parte posterior ou de serviço das residências.

Para o autor, o traçado de Goiás, apesar de irregular, mantém uma certa coerência e, definindo as prováveis influências arquitetônicas, revela que os becos estão mais próximos da arquitetura árabe denominada adarve do que de qualquer elemento ocidental. Citando Goitia, descreve que o adarve seria a negação da rua como valor estrutural, visto que não tem saída nem continuação, servindo apenas ao interesse privado, compreendido como o conjunto das casas em cujo interior se penetra através de sua passagem. Originalmente os becos teriam a função de atender a um número restrito de residências como acesso de serviço. Formados por detrás das ruas principais, funcionavam urbanisticamente como solução para a existência das extensas quadras e entrada de serviçais e animais. Os becos ligavam ruas e eram ladeados pelos muros dos quintais e, em algumas situações, tinham a função de escoamento das águas de rios e córregos. Muito comuns em Goiás, e nas demais cidades coloniais brasileiras, foram inventariados e imortalizados por Cora Coralina:

Becos da minha terra, discriminados e humildes, lembrando passadas eras...

Beco do Cisco.

Beco do Cotovelo.

Beco do Antônio Gomes.

Beco das Taquaras.

Beco do Seminário.

Bequinho da Escola.

Beco do Ouro Fino.

Beco da Cachoeira Grande.

Beco da Calabrote.

Beco do Mingu.

Beco da Vila Rica...

(Coralina, 2001a, p. 93)

$\mathrm{Na}$ maioria das vezes, recebiam o nome dos moradores mais expressivos ou de sua característica mais marcante. As denominações referiam-se a questões geográficas, a exemplo dos becos das Taquaras, do Mingu, do Ouro Fino, da Água Férrea e da Cachoeira Grande; de moradores ilustres ou instituições neles existentes, como os do Antônio Gomes, do Sócrates, dos Médicos, do Teatro, do Quartel, da Matriz, da Escola e do Seminário; de seu formato, como o Beco do Cotovelo, e de lendas e costumes como os becos do Calabrote e da Vila Rica. No livro Memórias e belezas da cidade de Goiás (1958), o escritor Goiás do Couto também retrata os becos como portadores de memórias e identidades:

Juntando pedaços do mosaico díspar de memórias, vamos pervagar na sonoridade quase doméstica de nomes de alguns recantos da 
cidade. [...] Sonora e típica é a nomenclatura das ruas e, de tanto nelas ouvir falar-se, com a mesma nos habituamos e somente ante o curioso espanto do forasteiro, num ponderado trabalho de análise, começamos a encontrar seu sabor genuíno. [...] Não fica apenas nisso a seqüência de nomes sugestivos porque os retorcidos, acanhados e filamentosos becos do Cisco, da Vila Rica, do Mingu, do Cotovelo, do Canivete, das Taquaras, das Violas, também se fazem presentes. (Couto, 1958, p. 12-14)

O estudo de Jardim (2001), A geografia poética da memória popular: leitura dos nomes e codinomes de ruas, becos, largos, praças e travessas da cidade de Goiás, fornece significativas informações sobre a relação entre os nomes oficiais e a toponímia popular. Segundo afirma, desde a época colonial o primeiro nome recebido pelos logradouros, antes da denominação oficial, se originava de um apelido ou codinome, muitos dos quais vigoram atualmente. A oficialização dos nomes, resultante do jogo pelo poder, tenderia a silenciar a história popular e, na maioria das vezes, buscava afastar os codinomes por questões políticas, conferindo às ruas denominações distantes da realidade da população. A autora compreende serem os codinomes locais privilegiados para a leitura dos modos de vida e representações de uma sociedade. Mas que história ou histórias contam os becos?

Conto a estória dos becos, dos becos da minha terra, suspeitos... mal afamados onde família de conceito não passava. "Lugar de gentinha" - diziam, virando a cara. De gente do pote d'água.

De gente de pé no chão.

Becos de mulher perdida.

Becos de mulheres da vida.

Renegadas, confinadas

na sombra triste do beco.

Quarto de porta e janela.

Prostituta anemiada,

solitária, hética, engalicada,

tossindo, escarrando sangue

na umidade suja do beco.

(Coralina, 2001a, p. 93-94)

Cora Coralina revela o beco como lugar de história e de marginalização. Tornou-se reposi- tório dos marginais e, por isso, deveria ser evitado, já que aliava ao cenário pobre, periférico e antiestético personagens considerados de hábitos, valores e costumes reprováveis. Dessa forma, não era recomendável às "famílias de conceito" o trânsito nesses espaços estigmatizados. Ao contar a história dos becos - "lugar de gentinha" -, a poetisa encontra um ponto de observação privilegiado da sociedade de seu tempo que não coincide com o adotado pela história oficial. Identifica-se com os pobres, os doentes, com a mulher da vida, enfim, com os "obscuros".

Todavia, os becos passaram a ter outra finalidade que superou a de simples acesso de serviço. A estagnação econômica em virtude da decadência da mineração, da crise do sistema oligárquico e, posteriormente, da mudança da capital para Goiânia contribuiu para que a considerada "boa sociedade" parcelasse seus terrenos. Pequenas casas foram construídas no fim de alguns quintais onde havia apenas muros e portões e lentamente se transformaram em locais dos marginalizados e destino de ações condenadas pela moralidade dominante. Os becos que anteriormente serviam como meio de passagem e entrada de serviço, com a construção das residências isoladas ou distanciadas, tornaram-se locais de transgressão, conflito e desordem. Discorrendo sobre as relações ocorridas no espaço da cidade de Goiás, Souza Filho (1987) relata: "Beco este que terminava numa pequena praça, apelidada de 'Covil das Mariposas'. Todas as casas foram construídas por Dr. José Neto de Campos Carneiro, que as alugava para soldados e mulheres de vida livre. Era reduto das 'prostitutas baratas' e local de constantes desordens e crimes" (Souza Filho, 1987, p. 116).

Compreender a sociedade goiana retratada na obra de Cora Coralina consiste em reconhecer suas divisões, perspectivas e códigos urbanos: a cidade separada por ruas e largos, expostos, em que foram edificados as igrejas, os monumentos civis e onde residiam os possuidores de maior capital social, e por becos, locais desprezados, repositórios de lixo, com casas pobres, escondidas no fundo dos quintais, para onde eram "empurrados" os personagens citados na obra da poetisa - pobres, deficientes mentais, negros, 
desempregados, desenganados, subversivos, obscenos, malandros e prostitutas sem prestígio. Essa demarcação contribuiu para que, no imaginário da cidade, os becos fossem associados ao desconhecido, a um local em que ocorriam coisas do "outro mundo":

Becos mal assombrados.

Becos de assombração...

Altas horas, mortas horas...

Capitão-mor - alma penada,

terror dos soldados, castigado nas armas.

Capitão-mor, alma penada,

num cavalo ferrado,

chispando fogo,

descendo e subindo o beco,

comandando o quadrado - feixe de varas...

Arrastando espada, tinindo esporas...

(Coralina, 2001a, p. 94)

Ao avaliar as cidades interioranas do Brasil como categoria passível de investigação social a partir de sua arquitetura, Roberto DaMatta (1997) afirma que o espaço se confunde com a ordem social, de forma que, "sem entender a sociedade com suas redes de relações sociais e valores, não se pode interpretar como o espaço é concebido. Aliás, nesses sistemas, pode-se dizer que o espaço não existe como uma dimensão social independente e individualizada" (DaMatta, 1997, p. 30). O autor pontua que, muitas vezes, as expressões que designam bairros e ruas exprimem regiões sociais convencionais e locais, indicando antigüidade ou sugerindo segmentação social e econômica. Nesse entendimento, ressalta que a diversidade de espaços e temporalidades convive simultaneamente, tornando-se característica da sociedade brasileira. DaMatta descreve espaços considerados problemáticos, como as regiões pobres e de meretrício, afirmando que, geralmente, são regiões periféricas escondidas por tapumes, jamais concebidas como permanentes ou complementares às áreas nobres, mas como locais de transição.

A cidade deve ser pensada através das formas com que os agentes se organizam e se apropriam de seu espaço físico. Desse modo, são as representações mentais que os agentes produzem sobre ela, como localidade produtora de "províncias de significado" e "regiões mo- rais", importantes mecanismos para a observação das relações travadas em seus cenários, e os territórios de sociabilidade, locus de sentidos produzidos por uma determinada comunidade. De acordo com Park (1973), o conceito de região moral é necessário para observar as formas com que os agentes se relacionam entre si no ambiente urbano. Os becos podem ser definidos como uma região moral, ou seja, uma região onde prevalece um código moral divergente. O local exerceria poder determinante sobre os indivíduos "desviantes", reforçando a sua identidade marginal. Identidade definida pela forma com que as pessoas desempenham seus papéis em ambientes determinados. Para Marques (2003),

podemos pensar a cidade em termos de províncias de significado mais ou menos demarcadas que possui, através dos tipos de sociabilidade que comporta. Como exemplos temos parques, praças e jardins, espaços de sociabilidade lúdica e práticas esportivas; trechos de bairros repletos de bares, restaurantes e lanchonetes, locais boêmios ou noturnos por excelência; lugares caracterizados pos shoppings, lojas e galerias ou ainda pelos tipos de serviço que oferecem; outros por casas de espetáculo, bingos etc; há regiões caracterizadas pela presença do tráfico de drogas e da prostituição; também há bairros apenas tidos como residenciais; e por fim, há espaços de passagem, que muitas vezes comportam o trânsito entre estas diversas regiões morais. [...] Existe uma certa ordenação - mesmo não sendo explícita - dos espaços da cidade quanto aos usos e às sociabilidades que comportam, ainda que sejam interpretados simbolicamente de diferentes maneiras pelas pessoas que os habitam. (Marques, 2003, p. 10)

Em Goiás, a vida dos moradores dessas províncias de significados que são os becos evidenciava a falta de perspectivas melhores:

Mulher-dama. Mulheres da vida, perdidas, começavam em boas casas, depois, baixavam pra o beco.

Queriam alegria. Faziam bailaricos.

- Baile Sifilítico - era ele assim chamado.

O delegado-chefe de Polícia - brabeza -

dava em cima...

Mandava sem dó, na peia. 
No dia seguinte, coitadas, cabeça raspada a navalha, obrigadas a capinar o Largo do Chafariz, na frente da Cadeia.

Becos da minha terra...

Becos de assombração.

Românticos, pecaminosos...

Têm poesia e têm drama.

O drama da mulher da vida, antiga, humilhada, malsinada.

Meretriz venérea,

Desprezada, mesentérica, exangue.

Cabeça raspada a navalha,

castigada a palmatória,

capinando o largo,

chorando. Golfando sangue.

(Coralina, 2001a, p. 94-95)

Registrando os personagens que habitavam os becos, a poetisa destaca o drama das "mulheres da vida", revelando as razões que as levaram a "cair na vida". Cora Coralina demonstra em contos e poesias que as mulheres avessas ao trabalho doméstico ou às atividades destinadas ao universo feminino, como as de lavadeira, carregadora de água, empregada, dentre outras, quando abandonadas pelo marido, ou quando se contrapunham às convenções sociais (gravidez fora do casamento ou concubinagem), eram entregues à sua própria sorte e, frequientemente, tornavam-se prostitutas. Quando não tinham condições de frequientar os cabarés ou as renomadas casas de prostituição da cidade, a alternativa encontrada era abrir uma casa no beco.

As mulheres que desfrutavam de algum prestígio abriam ou integravam casas de prostituição em locais mais afastados e eram financiadas por seus clientes, na maioria políticos, policiais e membros das famílias então dominantes; já para as destituídas de proteção, restavam os becos. Alencastro (2003) escreve que esses locais problemáticos eram preferencialmente situados em regiões pobres, as periferias, arredores do centro e em Goiás eram denominados de becos, "zona" ou "rua da lama". Lugares estigmatizados, abrigavam personagens que buscavam alegria e queriam viver livremente, mas que eram duramente reprimidos por incomodarem os padrões ditados pela moral dominante, cujo universo era representado pelo mundo da visibilidade. Por isso, o largo passou a ser o ambiente onde os castigos e punições deveriam ser realizados: "cabeça raspada a navalha, obrigadas a capinar o Largo do Chafariz, na frente da cadeia".

As condições apontadas pela poetisa coadunam-se com as lições de Foucault (1997), em Vigiar e punir, quando estudou as instituições penais, o terror e as imagens formuladas pelo sofrimento. Os castigos, punições e penas constituiriam parte de um ritual em que o sofrimento seria estabelecido em uma forma diferenciada, através do poder de punir e seus excessos. $\mathrm{O}$ terror se manifestaria a partir de uma série de instituições e discursos que responderiam ao exercício do poder em um determinado momento histórico. Para o autor, a "sociedade disciplinar" não se resumiria à imposição de castigos e limites, mas pelo adestramento de corpos, os denominados "corpos dóceis", em padrões de normalidade, instituindo a dominação por meio da vigilância e da punição sobre o intelecto, a vontade e as paixões dos indivíduos. Em suas análises, o isolamento ocasionaria a ruptura das trocas entre os seres. Os processos de vigilância e punição apresentariam algumas consequiências importantes, como um germe de controle no qual todos vigiam e são vigiados concomitantemente; a existência de uma relação entre a vigilância, a depredação e a punição; a diferenciação de comportamentos individuais definindo os exemplos a serem seguidos e desprezados, e os mecanismos de punição e vigilância como formas de padronização e controle. A punição, assim como a destinada às personagens retratadas na poesia, funcionaria como modo de promover a segregação a partir da identificação das aptidões e dos comportamentos e meio de instituir pressão, visando a que todos os "destoantes" se submetessem a um mesmo modelo de subordinação e passividade.

A imagem da "mulher da vida" na cidade de Goiás era comumente associada à repressão e à doença. De acordo com Karasch (1999), a sífilis foi a doença mais comum nas cidades mineradoras do século XVIII, onde a prostituição e a concubinagem eram comuns. Consultando relatos de governantes e de autoridades eclesiásticas, a pesquisadora detectou queixas constantes sobre a falta de moralidade sexual em Goiás. Já para Bittar (2002), a prostituição 
é uma das atividades importantes à análise da formação do povo goiano e, citando o viajante Saint-Hilaire, ressalta que no século XIX havia em Goiás um impressionante número de cabarés. A autora amplia as informações descritas pelos poemas de Cora ao citar um trecho do inventário de Antônio Ferreira Dourado, em que o titular havia emprestado "vinte e tantas oitavas de ouro a Anacleta Maria, mulher meretriz, para sair da cadeia, por intervenção do Procurador das causas de Vila Boa" (Bittar, 2002, p. 64).

De acordo com Lima (2005), são raros os estudos sobre a participação da mulher na história de Goiás, e os historiadores ainda não deram a elas o crédito devido, resumindo sua participação nas entrelinhas da historiografia. À mulher eram negados os prazeres do sexo, os sonhos e as vontades. Quando adolescentes, se tinham qualquer sentimento por alguém que não fosse da família escolhida para o casamento, "eram confinadas em casa. Saíam apenas na companhia dos pais e seu lazer eram as visitas familiares e as idas à igreja. Às vezes eram mandadas para colégios internos. Raros eram os casos de rebeldias às imposições clericais e familiares" (Lima, 2005, p. 1). Relata que as mulheres que não se casavam eram geralmente expulsas de casa e, se tivessem bens, eram deserdadas.

Em Goiás, aos que se desviavam do modelo restritivo de comportamento era aplicada a punição que impunha uma relação servil de docilidade e utilidade, necessária à manutenção da hierarquia social e de comando. A poetisa, ao retratar o "espetáculo" da vida nos becos, apresenta o destino dos personagens definindo o último ato:

\section{(ÚLTIMO ATO)}

Um irmão vicentino comparece.

Traz uma entrada grátis do São Pedro de Alcântara.

Uma passagem de terceira no grande coletivo de São Vicente.

Uma estação permanente de repouso - no aprazível São Miguel.

Cai o pano. (Coralina, 2001a, p. 95)

Na perspectiva de Cora, somente no ato final as pessoas "de conceito" compareciam ao núcleo do "proibido". Os marginalizados não deveriam se manifestar livremente, sob o risco da repressão. A sociedade só permitia suas saídas do beco para o São Pedro de Alcântara, o São Vicente e o São Miguel, respectivamente o hospital, o asilo e o cemitério da cidade de Goiás. Dessa forma, a sociedade destinava poucas opções aos pobres: o confinamento nos becos, nos hospitais e asilos ou a morte, formas eficazes de evitar, silenciar e esconder os indesejáveis. Vidas limitadas, escondidas, reprimidas, doença, velhice, loucura e morte resumem os caminhos dos que se encontravam à margem na sociedade goiana.

Discutindo a evolução da saúde e das doenças em Goiás de 1826 a 1930, Salles (1999) escreve que, na segunda década do século XIX, foram realizadas importantes mudanças sanitárias na província em decorrência de uma determinação do governo central para a instalação de hospitais nas capitais do império. Essas mudanças romperam com os hábitos tradicionais, e a busca pelo saneamento culminou com a instalação do Hospital de Caridade São Pedro de Alcântara, em 1825, e com a demarcação do cemitério, visto que até então os mortos eram sepultados nas igrejas. Já Moraes (1999) relata que a análise do discurso normativo sobre o espaço público de Goiás pressupõe a aplicação de uma estratégia desenvolvida pela classe dominante visando disciplinar e evitar "a mendicidade e o amontoamento de pessoas pelas praças e ruas, o que poderia facilitar a proliferação de doenças e impedir a circulação do ar" (Moraes, 1999, p. 135). A autora informa que, na cidade de Goiás, os interesses de classe estavam representados na denominada junta de caridade, que administrava o hospital e era composta por cidadãos abastados que viviam efetivamente na cidade. A partir de 1842, o hospital passou também a receber interferência da Assembléia Legislativa e da Câmara Municipal, e "os deputados e vereadores ressaltavam o perigo das aglomerações e acentuavam o risco de contaminação que os vadios e vagabundos proporcionaram com suas presenças. Assim resolveram contribuir para a implantação de medidas higienistas, associando desinfecção a submissão" (Moraes, 1999, p. 137).

O hospital tornou-se uma instituição para disciplinar os "desviantes", com o intuito de 
disseminar influências mais "adequadas" ao convívio social. Aliada a essa tentativa de saneamento empreendida pelo hospital, em 1859 foi concluído o cemitério público, com sepulturas individuais, porém a exclusão ainda continuava até mesmo com a morte. Analisando o cemitério de Goiás, Moraes se referiu à existência de uma "geografia social dos mortos":

No cemitério existiam, na entrada, terrenos para sepulturas de pagãos e acattholicos, bem como valas para recolher as águas dos terrenos contíguos ou para conduzi-las a algum ponto. Logo após, vinham as sepulturas para crianças, adultos e pessoas pobres que tinham entre dez e vinte anos e as sepulturas comuns, que custavam oito mil réis. $\mathrm{O}$ restante do terreno era dividido ao meio, com cada metade subdividida em quatro partes, recebiam túmulos para os órfãos, para a Irmandade do Carmo [pardos], para a Irmandade do Rosário [negros] e sepulturas de seis mil réis para crianças. As partes restantes seriam para os membros das Irmandades da Boa Morte, dos Passos, do Santíssimo e de Santa Bárbara. (Moraes, 1999, p. 149)

A autora conclui que o amontoamento de trabalhadores livres, de forros, de escravos, mendigos, doentes e vadios no espaço público representava perigo à classe dominante e, por isso, a necessidade das posturas sanitárias impostas como formas de controle social.

No mesmo raciocínio, posteriormente outra opção para a expulsão dos "indesejáveis" do contexto público foi o Asilo São Vicente de Paulo. Construído em 1909, o asilo tinha as funções de assistência social e religiosa e de confinamento para os portadores de doenças não contagiosas e idosos pobres. Em Memórias goianas $n^{\circ} 17$, observamos que sua instalação se realizou através do esforço de um grupo pertencente às "famílias de conceito", utilizando a instituição para a concretização de seus objetivos, pois "fez com que desaparecessem por completo das ruas grande número de mendigos de ambos os sexos" (2004, p. 20). A finalidade do asilo vem ao encontro das lições de Norbert Elias (2001), as quais compreendem que o envelhecimento, a doença e a morte são situações constantemente evitadas pela sociedade, ocasionando um isolamento precoce dos moribundos e demonstrando a dificuldade que as pessoas têm de identificação com esses segmentos. O autor descreve, através de um processo civilizador, a existência de uma maior exclusão possível da morte, dos velhos e dos moribundos da vida social e uma gradativa ocultação de fatos e experiências que evocam suas lembranças. Dessa forma, o "último ato", retratado por Cora, não apenas encerra a poesia, mas aponta o final da vida de inúmeros personagens marginalizados nas tramas de sua cidade.

\section{Considerações finais}

A análise do universo imaginário de Cora Coralina possibilitou-nos reconhecer a sua literatura como uma fonte privilegiada de conhecimento das relações histórico-sociais em Goiás, na transição dos séculos XIX e XX. Explorando o texto literário, percebemos que a poetisa realizou um retrato de sua sociedade que diverge, muitas vezes, do comumente desenvolvido por outros analistas. A autora tinha consciência de que era necessário promover uma revisão da história oficial e, através de sua poesia, efetuou um rearranjo, evidenciando aspectos e personagens até então destinados ao esquecimento. $\mathrm{O}$ compromisso com a memória, através do diálogo com as "vozes obscuras", lhe proporcionou reflexões sobre seu tempo e lugar que, além de terem singularizado a narrativa, são a grande contribuição literária da autora.

Sua estética, marcada por um aparente despojamento, reflete o que Machado (2002) identificou em Lima Barreto como "sensibilidade sociológica". Em sua perspectiva, a emergência dessa sensibilidade estaria atrelada às transformações que caracterizaram o processo de formação e consolidação da vida moderna no Brasil. Partindo desse entendimento, Cora e outros escritores teriam realizado uma opção temática pelos marginalizados por estarem, assim como os clássicos da sociologia, "estritamente vinculados às condições de emergência e configuração da sociedade capitalista no Brasil" (Machado, 2002, p. 8). Acreditamos que, tal como Lima Barreto, a inserção marginal da autora teria sido fundamental para a adoção de um posicionamento crítico e para a realização do seu projeto literário. Essa percepção estabe- 
lece pontos de contato com o que Bosi (2000) denomina poesia-resistência. Segundo afirma, toda grande poesia moderna apresenta uma forma de resistência simbólica aos discursos dominantes, "a consciência, quando amadurece e se aguça, chega à encruzilhada: ou a morte da arte, ou a reimersão no mundo-da-vida" (Bosi, 2000, p. 184). Uma das suas marcas constantes seria a coralidade: o poema assumiria o destino dos oprimidos no registro de sua voz. O coro dos dominados que conquistam voz no $t u$, no vós e no nós da poesia. É o que Cora faz, muitas vezes, em sua obra, conferindo aos oprimidos uma dignidade lírica, um "heroísmo poético que reabilita a periferia, a marginalidade, a clandestinidade, a poesia coralineana subverte e reorganiza a história oficial" (Yokozawa, 2002, p. 6).

Mas o que a poetisa revela no poema "Becos de Goiás"? Avaliando que os moradores dos becos não poderiam interagir com os demais nem se manifestar, somando-se ao destino que a sociedade a eles conferia, podemos observar uma rígida estratificação em Goiás. Segregação denunciada em diversos momentos pela literata: "dificuldades entrelaçadas. Falta de amparo, nem um apoio. Má vontade reinante. [...] Goiás, compartilhamento fechado por todos os lados. Em volta, o sertão. Dentro da cidade, ruas delimitando classes, orgulho de família, preconceitos sociais, coisinhas, rotina..." (Coralina, 2000, p. 101-102)

Cora Coralina definiu as características gerais dos becos, seus personagens e as situações de clausura, doença, velhice e morte a que estavam destinados. A autora retratou hierarquias que deveriam conter os "indesejáveis" e construiu uma declaração de afeto ao amar e cantar com ternura o considerado "errado" da sua terra. Ao invés de poetizar a realidade a partir dos monumentos reconhecidos pelo poder institucionalizado, descreve-a da periferia, das injustiças e violências, construindo um contundente testemunho da estrutura autoritária, preconceituosa e excludente de seu tempo.

\footnotetext{
Abstract: This paper analyzes the interconnections between literature and society in the poem "Becos de Goiás" of Cora Coralina (1889-1985). In it, we observe the socials relations on Brazilian interior in centuries XIX
}

and $\mathrm{XX}$, under the look of periphery, of that they were to the edge in considered "the good society", thronging sceneries, personages and destinies that diverges of traditional privileged. Intend, with the alleys, coronary valves of its old city, to analyze the strategies use by authoress for to portray and to criticize the reality of your time.

Key-words: city; poetry; society.

\section{Referências}

ALENCASTRO, Jane de. Memórias de Aninha. In: Leitura: teorias e práticas. Goiânia: Editora Vieira, 2003.

BITTAR, Maria José Goulart. As três faces de Eva na cidade de Goiás. Goiânia: Kelps, 2002.

BOLLE, Willi. Fisiognomia da metrópole moderna: representação da história em Walter Benjamin. 2. ed. São Paulo: Editora da Universidade de São Paulo, 2000.

BOSI, Alfredo. O ser e o tempo da poesia. 6. ed. São Paulo: Companhia das Letras, 2000.

BOURDIEU, Pierre. As regras da arte: gênese e estrutura do campo literário. São Paulo: Companhia das Letras, 1996a.

A ilusão biográfica. Usos \& abusos da história oral. Rio de Janeiro: Editora da Fundação Getúlio Vargas, 1996b.

BRASIL. Proposição da inscrição da cidade de Goiás na Lista do Patrimônio Mundial. Brasília: Ministério da Cultura; Ministério das Relações Exteriores, 1999.

CAMPOS, F. Itami. Coronelismo em Goiás. 2. ed. Goiânia: Vieira, 2003.

CANDIDO, Antonio. Literatura e sociedade: estudos de teoria e história literária. 5. ed. São Paulo: Editora Nacional, 1976.

CHAUL, Nars Fayad. Caminhos de Goiás: da construção da decadência aos limites da modernidade. 2. ed. Goiânia: Ed. da UFG, 2002.

COELHO, Gustavo Neiva. Goiás: uma reflexão sobre a formação do espaço urbano. Goiânia: Ed. UCG, 1996.

CORALINA, Cora. Poemas dos becos de Goiás e estórias mais. 20. ed. São Paulo: Global, 2001a.

. Villa Boa de Goyaz. São Paulo: Global, 2001b.

Vintém de cobre: meias confissões de Aninha. 8. ed. São Paulo: Global, 2001c.

O tesouro da casa velha. 3. ed. São Paulo: Global, 2000.

COUTO, Goiás do. Memórias e belezas da cidade de Goiás. Goiás, 1958. 
DaMATTA, Roberto. A casa \& a rua: espaço, cidadania, mulher e morte no Brasil. 5. ed. Rio de Janeiro: Rocco, 1997.

ELIAS, Norbert. A solidão dos moribundos seguido de envelhecer e morrer. Rio de Janeiro: Jorge Zahar Ed., 2001.

FOUCAULT, Michel. Vigiar e punir: nascimento da prisão. Petrópolis, RJ: Vozes, 1997.

FRAGA, Ademar Duarte. Goiás, Patrimônio da Humanidade: aproveitamento socialmente compartilhado ou exclusão social? Goiânia, 2005. Dissertação (Mestrado em Sociologia) - Faculdade de Ciências Humanas e Filosofia, Universidade Federal de Goiás.

JARDIM, Rosimar Coelho Magalhães da Veiga. A geografia poética da memória popular: leitura dos nomes e codinomes de ruas, becos, largos, praças e travessas da cidade de Goiás. Cidade de Goiás, 2001. Monografia. (Especialização em Leitura: Teorias e Práticas) - Unidade Universitária Cora Coralina, Universidade Estadual de Goiás.

KARASCH, Mary. História das doenças e dos cuidados médicos na capitania de Goiás. In: FREITAS, Lena Castello Branco Ferreira de (Org.). Saúde e doenças em Goiás: a medicina possível. Goiânia: Ed. da UFG, 1999.

LIMA, Maísa. Dócil, frágil e submisso: mulher goiana do século 19 vivia à sombra da figura masculina. $O$ Popular, Goiânia, 7 mar. 2005.

MACHADO, Maria Cristina Teixeira. Lima Barreto: um pensador social na Primeira República. Goiânia: Ed. da UFG; São Paulo: Edusp, 2002.

MARIN, Joel Orlando Bevilaqua. Os programas de erradicação do trabalho infantil. Revista da UFGInfância, $\mathrm{n}^{\circ}$ 2. Goiânia: Editora da UFG, 2004.

MARQUES, Olavo Ramalho. Corpo e espaço como categorias para se conhecer uma cidade: um estudo sobre diversidade cultural, formas de sociabilidade e identidade no $3^{\circ}$ Fórum Social Mundial em Porto Alegre/RS. Porto Alegre: Banco de imagens e efeitos visuais, UFRGS, 2003.

MEMÓRIAS Goianas $n^{\circ}$ 17. Sociedade Goiana de Cultura. Goiânia: Ed. da UCG, 2004.

MORAES, Cristina de Cássia Pereira. O Hospital de Caridade São Pedro de Alcântara e os trabalhadores na cidade de Goiás (1830-1860). In: FREITAS, Lena Castello Branco Ferreira de (Org.). Saúde e doenças em Goiás: a medicina possível. Goiânia: Ed. da UFG, 1999.

PALACIN, Luís. MORAES, Maria Augusta de Sant'Ana. História de Goiás. 5. ed. Goiânia: Ed. da UCG, 1989.

PARK, Robert. A cidade: sugestões para a investigação do comportamento humano no meio urbano. In: VELHO, Otávio (Org.). O fenômeno urbano. Rio de Janeiro: Zahar Editores, 1973.

SALLES, Gilka Vasconcelos Ferreira de. Saúde e doenças em Goiás (1826-1930). In: FREITAS, Lena Castello Branco Ferreira de (Org.). Saúde e doenças em Goiás: a medicina possível. Goiânia: Ed. da UFG, 1999.

SILVA, Rita de Cássia da. Uma leitura interdisciplinar da poética de Cora Coralina. In: Leitura: teorias e práticas. Goiânia: Editora Vieira, 2003.

SOUZA FILHO, Eduardo Henrique de. Canteiro de saudades: evocações e memórias. Goiânia: Poligráfica, 1987.

YOKOZAWA, Solange Fiúza Cardoso. Confissões de Aninha e memória dos becos: a reinvenção poética da memória em Cora Coralina. Anais do Terceiro Encontro de Professores de Letras do Brasil Central. Brasília, Universidade de Brasília, out. 2002. 